This item was submitted to Loughborough's Research Repository by the author.

Items in Figshare are protected by copyright, with all rights reserved, unless otherwise indicated.

\title{
Children's rights and the regulations on the transfer of young players in football
}

PLEASE CITE THE PUBLISHED VERSION

https://doi.org/10.1177/1012690218786665

\section{PUBLISHER}

(C) The authors. Published by SAGE Publications

\section{VERSION}

AM (Accepted Manuscript)

\section{PUBLISHER STATEMENT}

This work is made available according to the conditions of the Creative Commons Attribution-NonCommercialNoDerivatives 4.0 International (CC BY-NC-ND 4.0) licence. Full details of this licence are available at: https://creativecommons.org/licenses/by-nc-nd/4.0/

\section{LICENCE}

CC BY-NC-ND 4.0

\section{REPOSITORY RECORD}

Yilmaz, Serhat, James Esson, Paul Darby, Eleanor Drywood, and Carolynne Mason. 2018. "Children's Rights and the Regulations on the Transfer of Young Players in Football”. figshare. https://hdl.handle.net/2134/33594. 
Children's rights and the regulations on the transfer of young players in football *Serhat Yilmaz, Lecturer - School of Sport, Exercise and Health Sciences, Loughborough University, UK: s.yilmaz@lboro.ac.uk

*corresponding author

James Esson, Lecturer - School of Social, Political and Geographical Sciences, Loughborough University, UK: j.esson@lboro.ac.uk

Paul Darby, Reader - School of Sport, Ulster University, UK: p.darby@ulster.ac.uk

Eleanor Drywood, Senior Lecturer - Liverpool Law School, University of Liverpool, UK: e.w.drywood@liverpool.ac.uk

Carolynne Mason, Lecturer - School of Sport, Exercise and Health Sciences, Loughborough University, UK: c.l.j.mason@lboro.ac.uk

Version: Accepted for publication (please cite published version). 


\section{Children's rights and the regulations on the transfer of young players in football}

\section{Abstract}

Children who interact with football's recruitment and transfer processes encounter a complex web of regulations and practices. Debates over how to ensure that the interests and well-being of young football players are adequately protected, and that risks to their rights and welfare are identified and addressed, have become a topic of academic, political, and media concern. This commentary article provides an overview of the Fédération Internationale de Football Association (FIFA) regulations concerning the mobility and representation of minors in player recruitment processes, in particular the Regulations on the Status and Transfer of Players (RSTP) and the Regulations on Working with Intermediaries (RWI). We examine these regulations through the lens of the United Nations Children's Rights Conventions (UNCRC). In so doing, the article demonstrates how football's regulatory frameworks and commercial practices inadvertently yield consequences that operate against the best interests of children involved in the sport. To counteract this, it is proposed that all planning, implementation, monitoring, and evaluation of regulations involving the recruitment and transfer of young people should be explicitly informed by globally accepted standards of children's rights, such as the UNCRC. More specifically, it is argued that FIFA should adopt an approach that places the child at the centre of regulatory frameworks and characterises the child as a 'rights holder'.

\section{Key words}

Children's Rights; FIFA; Football; Intermediaries; Minors

\section{Introduction}


The last two decades have witnessed an ongoing debate involving sports governing bodies, Non-Governmental Organisations (NGOs), politicians, the media and the United Nations (UN) about the best ways to ensure the interests and well-being of young football players are adequately protected, and risks to their rights and welfare are identified and addressed (see Brackenridge et al., 2006; Darby et al., 2007; Esson and Drywood, 2018; European Commission, 2007; Meneses, 2013; Hawkins, 2015). To date, the primary response by the Fédération Internationale de Football Association (FIFA) is the introduction of protective measures governing the mobility and representation of minors in football's recruitment processes. A regulatory regime for the protection of these players in transfers was established within the Regulations on the Status and Transfer of Players (RSTP). Originally adopted in 2001 and modified in $2005,2009,2015$, and 2018 , these regulations appear well-intentioned and are motivated by a desire not only to bring order to the international movement of young players but also to minimise the potential for their human trafficking or abuse in the process (FIFA, 2016). Additionally, FIFA has recently ratified a new set of rules, Regulations on Working with Intermediaries (RWI), that governs the activities of intermediaries in football (previously known as 'players' agents') within which a stricter approach to the representation of minors is introduced (FIFA, 2014).

To date, there has been a limited consideration of the connections between children's rights theory and the regulations of the football industry related to recruitment and transfer practices. ${ }^{1}$ This is not a surprising development given the insistence of sports governing authorities on the autonomy of sport and their resistance to any form of legal scrutiny from outside (Geeraert et al., 2013). Therefore, while it is now accepted that sport must operate in a way that respects the principles underpinning wider legal systems (Garcia and Meier, 2016), the application of human rights principles to sport 
remains patchy. Sport's prevailing competitive and elitist cultures have not proven to be a fertile ground for any meaningful discussion of the interaction between children's rights and the impact of sport on the lived experiences of participants. According to Donnelly and Petherick (2004: 3001) 'almost half the 40 articles dealing directly with children's rights are occasionally or routinely violated when we consider children's involvement... with sports'. Yet, the representatives of football players, and athletes in general, have been pushing for a change to the system to uphold the human rights of their members including those who are minors. The World Players Association (WPA)², for instance, have recently adopted the Universal Declaration of Players Rights which is the first comprehensive articulation of athletes' rights with a view to setting a benchmark in the sports industry to protect, respect, and guarantee those rights (WPA, 2017).

This commentary article therefore provides a timely and critical contribution to this field by, for the first time, examining FIFA's RSTP and RWI in relation to an internationally recognised framework concerned with upholding, protecting and realising children's rights, that is the United Nations Conventions on the Rights of the Child (UNCRC). The UNCRC is the most successful rights treaty in existence because it is signed by every country in the world and ratified by all except the United States. Hence, the Convention represents globally accepted norms and standards of children's rights (David, 2005). Whilst state parties are the addressees of the UNCRC, its principles are now enshrined in global legal systems. As such, a UNCRC-informed approach places obligation on a range of 'duty bearers' who 'have an active role to play in ensuring that the rights of the young people in their care are secured' (Shrestha and Giron, 2006: 8). These duty-bearers can include public and private bodies including sports governing bodies, charities and NGOs, as well as individuals (Clapham, 1993). 
Therefore, as well as outlining the scope and content of rights, the UNCRC is a useful tool for assessing the effectiveness of laws, regulations and policies in upholding the rights of the child because it allows for an examination of the interactions between the child and a range of actors within society (Kilkelly, 2006).

By bringing the FIFA RSTP and RWI into a conversation with the UNCRC, this article identifies alignments and tensions between current regulations concerning the protection of minors within the football industry and globally accepted standards of children's rights. It also demonstrates how football's regulatory structures and commercial practices associated with player recruitment inadvertently yield consequences that may operate against the best interests of children involved in the sport. Subsequently, it is argued that these limitations and tensions can be alleviated, and in some cases potentially resolved, by adopting an approach that places the child at the centre of regulatory frameworks. The article is structured as follows. Section 2 provides a concise introduction of the UNCRC as a conceptual framework for the examination of FIFA's regulations governing the mobility and representation of minors in the recruitment and transfer processes in football which is presented in Section 3. Methodologically, alongside using the UNCRC as our conceptual framework, we have also undertaken a systematic documentary review of the FIFA RSTP and RWI to determine the relevant regulatory provisions that are applicable to the movement and representation of young players in football. Then, we critically examined the amenability and compatibility of those provisions with the UNCRC. Finally, we conclude by offering some recommendations as to how FIFA's regulations concerning the protection of minors within the football industry can be reconceptualised to better ensure that the rights, interests, and well-being of young football players are adequately protected. 


\section{The United Nations Conventions on the Rights of the Child}

The UNCRC, introduced in 1989, underpins our examination of FIFA's regulations on the protection of minors within the football industry. The UNCRC is used as a conceptual framework in two interrelated ways; firstly, for understanding the scope of content of children's rights; secondly, to gauge the amenability of FIFA's regulations with globally accepted standards of children's rights both in law and policy. The UNCRC defines a 'child' as every human being under the age of 18 years (Article 1), which is in line with FIFA's definition of a minor/young player. ${ }^{3}$ The UNCRC enumerates a wide-ranging set of rights and enshrines several substantive rights held by children that impact upon most areas of a child's life, which makes it a particularly useful framework for identifying where children's rights violations may occur in the recruitment of players within the football industry. These substantive rights include, amongst others, the right to life (Article 6), family life rights (Article 9 and 10), the right to health (Article 24), the right to an adequate standard of living (Article 27), education rights (Articles 28 and 29) and the right to relaxation and play (Article 31). In addition, there is an obligation placed on governments to protect children from violence, abuse and neglect (Article 19), economic exploitation (Article 32), sexual exploitation (Article 34), other forms of exploitation (Article 36), and abduction, sale and trafficking (Article 35).

Underpinning these rights in specific areas, the UNCRC also outlines four crosscutting principles which are to be applied when making decisions that affect children, or when elaborating laws and policies which impact upon them. These are: 
- Primary consideration must be given to the best interests of the child in all actions affecting them (Article 3(1))

- The child has a right to participation in all matters affecting them (Article 12)

- The child has a right to survival and development (Article 6)

- The child has a right to non-discrimination (Article 2)

Taken together, these principles provide a children's rights ethos, which can be used to examine actors' engagement with, and treatment of, children. The next section of the article operationalises the UNCRC as described above. It provides a succinct, non exhaustive, discussion of FIFA regulations in question, the RSTP and the RWI, concerning the recruitment of minors within the football industry and examines these in relation to the UNCRC.

\section{Regulations governing the recruitment practices of young players in football}

\subsection{Mobility of minors under the FIFA RSTP}

At the heart of FIFA's regulatory regime for the protection of minors in football is Article 19 of the RSTP setting out key principles of the system (Yilmaz, 2018) which restrict the mobility of young players by prohibiting international transfer of players under the age of 18 (FIFA RSTP 2018, Article 19.1). The prohibition also extends to the first registration with a club in a country where the minor is not a national (FIFA RSTP 2018, Article 19.3). There are four statutory exceptions to the rule; the parent rule, the EUEEA rule, the 50+50 rule, and the five-year rule (FIFA RSTP 2018, Article. 19.2 and 19.3). First, the parents-rule permits the international transfer of minors if their families move to the country of the new club for reasons not linked to football (FIFA RSTP 
2018, Article 19.2a). Second, the EU-EEA rule enables minors aged between 16 and 18 to be transferred within the European Union (EU) and the European Economic Area (EEA) providing that their new clubs guarantee their sporting and academic/educational training in line with the highest national standards and make provisions for their welfare in the best possible way (FIFA RSTP 2018, Article 19.2b). The $50+50$ rule takes into account the situation of young players living within the vicinity of borders and enables those who live no further than $50 \mathrm{~km}$ of a national border to register with a club in a neighbouring association, which is also located within $50 \mathrm{~km}$ of the national border provided they continue to live at home (FIFA RSTP 2018, Article 19.2c). The five-year rule is only applicable to the first registration of a minor allowing the registration to a club in a country that the player is not a national but has continuously lived for at least five years immediately prior to the intended first registration (FIFA RSTP 2018, Article 19.3).

This regulatory regime, which is based upon the mobility restriction, contradicts with the key principles and standards of the UNCRC. Firstly, the ban on the international transfers of minors significantly undermines a child's right to be heard in all decisions affecting them and to have their views given due weight according to their age and maturity (UNCRC, Article 12). In fact, a faithful reading of the UNCRC requires relevant bodies to provide a framework whereby a child can participate in decisions affecting them where their opinions are given due consideration, something which FIFA's outright ban does not offer. Where a football club with infrastructure to train and educate a player offers an opportunity to improve a player's life chances, it is perhaps understandable that a player and their family see no reason why they should not pursue this opportunity. In fact, the research has pointed to the prudence and agency that some young players display when choosing to migrate internationally for 
footballing purposes (Agergaard and Ungruhe, 2016; Esson, 2015a; Van der Meij et al., 2016). Therefore, instead of the blanket international transfer ban, young players should perhaps be provided with an opportunity to make 'informed decisions' about the circumstances associated with a transfer. This decision-making should occur alongside FIFA's scrutiny of each transfer that involves a minor on a case by case approach to ensure, and to confirm, that young players are provided with adequate training, education and welfare standards by their new clubs in line with the UNCRC.

Secondly, the UNCRC best interests' principle asserts that decisions are tempered by the need to protect children from harm when there are welfare concerns around the consequences of choices they make. The ban on the international transfer of minors and the exceptions, in particular the parents rule and 50+50 rule, were put in place with the intention of keeping children with their parents and families (which resonates with Article 9 of the UNCRC) while protecting them from harmful practices surrounding player transfers across international borders (UNCRC, Article 16), specifically the cases of human trafficking (see Esson, 2015b). Yet, the practices of exploitation and trafficking of minors continue to thrive, even with this ban in place (Meneses, 2013; Drywood, 2016). FIFA (2015) even acknowledges that there is an increased number of international transfers of players at a very young age (as early as 10 years old). At the same time, young players are denied the opportunity to pursue a career in football under circumstances that might improve their life chances substantively and better uphold their rights (unless one of the exceptions of the FIFA RSTP is met). To what extent such an approach is in the best interest of those young players is open to debate. For disadvantaged, but talented young players, an opportunity to play football combined with adequate levels of training, education, and welfare standards may be a better option than staying in a country where social conditions are poor and their 
economic opportunities are constrained. For these reasons, a re-examination of regulations concerning the migration of minors is needed. A focus needs to be given to improving conditions for young players in ways that are commensurate with the UNCRC (training infrastructures, educational opportunities, welfare standard, meaningful dual career ethos) rather than simply restricting their mobility.

\subsection{Representation of minors under the FIFA RWI}

Intermediaries in football (formerly known as 'player's agents') have emerged as one of the most powerful actors in the recruitment process of players, operating as a bridge between players and clubs (Poli, 2010). The new regulatory framework of FIFA, the RWI, came into force in 2015 superseding the previous licensing-based regime that had been in place since 1995 (Rossi et al., 2015). A key protective measure concerning minors under the new regime is a prohibition of payments to intermediaries for their services provided to young players. Clubs and players are not allowed to make any payments to intermediaries if the player concerned is a minor (FIFA RWI 2015, Article 7.8). Additionally, legal guardians of a minor are now required to sign the representation contract that the player enters into with an intermediary (FIFA RWI 2015, Article 5.2). In contrast, the RWI does not contain any limitation on the maximum duration of representation contracts between players and intermediaries (FIFA RWI

2015, Article 5) or a minimum age requirement for players when they can sign a representation contract. In practice, therefore, it is possible for an intermediary to contract with a minor for an extended period without any restriction. Moreover, the RWI has effectively de-regulated the agent market by abolishing the licensing requirement to practice the profession and anyone without a criminal record can now 
be registered as an intermediary. The implementation of the FIFA RWI by national football federations also varies globally causing a regulatory inconsistency. While some national associations fully prohibit the representation of minors (e.g. Portugal and Japan), others, such as Slovakia, China and the Czech Republic, allow intermediaries to receive remunerations from minors if a player is aged between 15 and 18 (Colucci, 2016).

The regulatory incoherency caused by the inconsistent implementation of RWI at the global level has created a wild west scenario, whereby the rights and welfare of children are placed at a significant risk. Firstly, the de-regulation offers a platform for unqualified individuals to operate in the player recruitment domain thereby lowering professional standards (Eppel and Miller, 2014) which is detrimental to the interest of young players. A recent FIFA Transfer Matching System (TMS) report (2017) underlines the importance of age as a factor in determining how often intermediaries are involved in transfers on the behalf of players. According to the analysis of international transfers between 2013 and 2017 registered with the FIFA TMS, players under the age of 18 represent the highest percentage (17.6\%) who used the intermediary services in international transfers. Between 18 and 25 years of age, the percentage dropped to $15.2 \%$, between 26 and 32 it further decreased to $14.5 \%$, and players over the age of 33 only engaged with intermediaries in 10.9\% of tranfers (FIFA TMS, 2007: 7). Young players clearly need a proper guidance in making strategic decisions about their carreers and the role of an intermediary in the process can be crucial. Nonetheless, the current system allows anyone to be an intermediary without assessing their level of knowledge of football industry and the transfer market meaning that minors may not always receive the most adequate advice in transfers. 
Secondly, the lack of restriction on the duration of the representation contracts, combined with the remuneration prohibition, paves the way for intermediaries to exercise a direct influence over young players by dictating contractual terms and transfers that ensure their financial return rather than negotiating conditions that are in the best interest of the player (UNCRC, Article 3). Because of the remuneration prohibition, intermediaries inevitably would seek to sign long-term representation agreements with a view to contractually tie young players down beyond their $18^{\text {th }}$ birthdays, so that they can receive remuneration for their services. Additionally, the long-term contracts are likely to lead to contentious disputes and litigation between players and intermediaries (De Marco, 2015). A prolonged representation contract may not only be open to a restraint of trade challenge but also frustrate a player's career by tempting them to break such agreements. Therefore, both regulatory provisions of the RWI, the lack of restriction converning the duration of the representation contracts and the remuneration prohibition, do not serve for the best interest of minors and directly contradict with the underlying principles of the UNCRC.

Finally, the other potential danger of the RWI's approach to the representation of minors is that it encourages the commodification of young players for commercial interest, which can be at odds with a child's right to be protected from economic exploitation (UNCRC, Article 32). An example of how this kind of arrangement can be problematic is third-party ownership (TPO) where a third party takes ownership of a player's economic rights and can profit from the player's movements within the football industry, e.g. by taking a share of future transfer fees (KPMG, 2013). Up until FIFA's global ban of the TPO in 2015, the ownership of young players was a wide-spread practice in football. In an investigation of child labour in the Latin American football industry, Meneses (2013) illustrates how football in Argentina, Brazil, Chile, Colombia, 
Ecuador, Mexico and Peru is increasingly populated by individuals seeking to buy the commercial rights of talented players as young as nine years old. According to Bruinewoud and Bossart (2016: 127), 'most young players in South America are subject to TPO, with the level reaching almost 90 percent in Brazil'. This situation is not unique to Latin America, and similar activities have been observed in West Africa (Esson, 2015a). Overall, despite a well-intentioned rationale behind the prohibition of remunerations from transfers involving minors, the RWI contravenes with the UNCR and its practical implications appear to be detrimental to young players.

\section{Conclusions: placing the child at the centre of regulations}

This commentary article contributes critically to debates over the protection of young people within the football industry by examining the FIFA regulations governing the international transfer and representation of minors through the lenses of the UNCRC. It has documented the tension between upholding children's rights and ensuring a free-flowing and liberal market in football and the availability of young talent, which has the (normally unintended) consequence of operating against the best interests of the child (as recognised in Article 3(1) UNCRC). This tension as well as other inconsistencies that raise challenges to the realisation of children's rights are the result of regulatory frameworks that fail to take into account young people's views at every stage of the rule design and formulation process.

The key conclusion of this article, therefore, is that football's governing bodies and relevant institutions can begin to alleviate and remedy the tensions and issues outlined above by engaging with, and embedding, a children's rights-based approach within regulations on children's involvement in football. The current lack of a rights-based 
approach in the regulatory design in football can also explain the regulatory incoherency outlined within this paper. As young players and their rights as a child are not at the heart of the process, the unitended consequences of the regulations are contradictory with the UNCRC. Consequently, it is imperative that an approach that characterises the child as the 'rights holder' and places the child at the centre of regulatory planning to be adopted. Such an approach would help to ensure that the principles underpinning the planning, implementation, monitoring and evaluation of regulations involving the recruitment of young players always place an emphasis on protecting and realising children's rights over commercial interests. A starting point for such a move would be ensuring that future responses to this issue, regulatory and otherwise, are explicitly informed and guided by an internationally recognized framework concerned with upholding and protecting children's rights, such as the UNCRC. To conclude, Table 1 below provides an overview of how such an approach could be achieved by football governing bodies and other stakeholders. 
Developing a rights-based approach in football means:

- Putting children at the centre, recognising them as rights-holders and social actors in football.

- Holding a holistic vision of the rights of the child while making strategic regulatory measures and taking specific actions in the governance of football.

- Using participatory and empowering approaches within the governance system of football allowing the involvement of children in various processes.

- Giving priority to children and a child friendly environment in football.

- Building partnerships and alliances within football involving governing bodies and other stakeholders for promotion of the rights of the child.

- Encouraging legal and other reforms, such as the establishment of regular auditing and monitoring mechanisms, which create a much greater likelihood of upholding the rights of the child and a long-term sustainable change in football.

Table 1: The implementation of a rights-based approach in the regulatory environment of football.

\section{Funding Acknowledgements:}

The research informing this article was conducted as part of a UNICEF funded project on the protection of minors in professional football.

\section{Conflict of Interest:}

N/A

Word Count: $\mathbf{3 , 7 8 1}$ 


\section{Notes:}

${ }^{1}$ An excellent body of work on child protection in sport, which addresses aspects of the football industry, has been produced e.g. by Celia Brackenridge and Paolo David, however to our knowledge no systematic analysis of recruitment practices within the global football industry with specific reference to children's rights has yet been undertaken.

2 The World Players Association is a representative organisation that brings together 85,000 players through more than 100 player associations in over 60 countries. It defines its role as being responsible for ensuring that the voice of organised players is heard at the highest levels in the decision-making of international sport.

${ }^{3}$ The definition of a minor is provided under the preamble of the FIFA RSTP (2018) and reads "a player who has not reached the age of 18" 


\section{References:}

Agergaard, S., \& Ungruhe, C. (2016) Ambivalent Precarity: Career Trajectories and Temporalities in Highly Skilled Sports Labour Migration from West Africa to Northern Europe. Anthropology of Work Review, 37(2), 67-78.

Brackenridge, C., Pitchford, A., Russell, K., \& Nutt, G. (2006) Child welfare in football: An exploration of children's welfare in the modern game. Routledge.

Bruinewoud, A. G., Bossart, G. (2016) Origins, practice and regulation of thirds-party ownership in South America, in Transparency International Global Corruption Report: Sport, Routledge. 127-129

Clapham, A. (1993) Human rights in a private sphere. Oxford: Clarendon Press

Colucci, M (ed.) (2016) The FIFA Regulations on Working with Intermediaries: Implementation at national level., International Sports Law and Policy Bulletin, 1/2016

Darby, P., Akindes, G., \& Kirwin, M. (2007) Football academies and the migration of African football labour to Europe. Journal of Sport and Social Issues, 31(2), 143-161.

David, P. (2005) Human rights in youth sport: a critical review of children's rights in competitive sport. Routledge

De Marco, N. (2015) The new FA intermediaries' regulation and disputes likely to arise. Available at: $\quad$ https://www.lawinsport.com/topics/articles/item/the-new-faintermediaries-regulations-disputes-likely-to-arise

Donnelly, P., \& Petherick, L. (2004) Workers' playtime? Child labour at the extremes of the sporting spectrum. Sport in society, 7(3), 301-321. 
Drywood, E. W. (2016) "When we buy a young boy...": Migrant Footballers, Children's Rights and the Case for EU Intervention', in I. Iusmen, \& H. Stalford (Eds.) The EU as a Children's Rights Actor. Barbara Budrich. 191-219

Eppel, M. \& Miller, J. (2014) A critical review of FIFA's 'Working with Intermediaries Regulations' 2015. Available at: https://www.lawinsport.com/topics/articles/item/acritical-review-of-fifa-s-working-with-intermediaries-regulations-2015

Esson, J., \& Drywood, E. (2018) Challenging popular representations of child trafficking in football. Journal of Criminological Research, Policy and Practice DOI 10.1108/JCRPP-01-2018-0005

Esson, J. (2015a) You have to try your luck: male Ghanaian youth and the uncertainty of football migration. Environment and Planning A, 47(6), 1383-1397.

Esson, J. (2015b) Better off at home? Rethinking responses to trafficked West African footballers in Europe. Journal of Ethnic and Migration Studies, 41(3), 512-530.

European Commission (2007) White Paper on Sport. Available at: http://ec.europa.eu/sport/documents/wp on sport en.pdf.

García, B. and Meier, H. E. (2016). Global sport power Europe? The efficacy of the European Union in global sport regulation. Journal of Common Market Studies, 2016, $1-21$.

Geeraert, A., Scheerder, J. and Bruyninckx, H. (2013) The governance network of European football: introducing new governance approaches to steer football at the EU level. International Journal of Sport Policy and Politics, 5(1), 113-132.

Fédération Internationale de Football Association (2014) Circular No. 1417. Available at: 
https://www.fifa.com/mm/document/affederation/administration/02/33/57/54/circularn o.1417-newregulationsonworkingwithintermediaries neutral.pdf

Fédération Internationale de Football Association (2015) Circular No. 1468. Available at:

http://resources. fifa.com/mm/document/affederation/administration/02/51/06/50/circul arno.1468 e neutral.pdf

Fédération Internationale de Football Association (2015) Regulations on Working with Intermediaries.

Available

at:

https://img.fifa.com/image/upload/cr6dquxm2adupv8q3ply.pdf

Fédération Internationale de Football Association (2016) Protection of minors FAQ. Available at: http://resources.fifa.com/mm/document/affederation/administration/02/83/14/23/faq protectionofminors august2016 en english.pdf

Fédération Internationale de Football Association Transfer Matching System (2017) Intermediaries in International Transfers, 2017 Edition. Available at: https://www.fifatms.com/data-reports/reports/

Fédération Internationale de Football Association (2018) Regulations on the Status and Transfer of Players. Available at: http://resources.fifa.com/image/upload/regulations-on-the-status-and-transfer-ofplayers-2018.pdf?cloudid=dpeoteqewi8f5doahly7

Hawkins, E (2015) The lost boys: Inside football's slave trade. Bloomsbury. 
KEA, CDES, EOSE, (2009). Study on sports agents in the European Union: A study commissioned by the European Commission. Available from: http://ec.europa.eu/sport/library/studies/study-sports-agents-in-eu.pdf

Kilkelly, U. (2016) The Convention on the Rights of the Child after Twenty-Five Years. Handbook of Children's Rights: Global and Multidisciplinary Perspectives, 80.

KPMG (2013) Project TPO. Available at: https://www.ecaeurope.com/media/1682/tporeport.pdf

Meneses, J. P. (2013) Niños futbolistas. Blackie Books.

Poli, R. (2010) 'Agents and intermediaries' in Chadwick S (Ed) Managing Football: An International Perspective. Oxford: Butterworth Heinemann, 201-216.

Riach, J (2015) 'Football Agents Fear 'Wild West' as FIFA Reforms Seek to Cap Fees' Available at: https://www.theguardian.com/football/2015/mar/31/football-agents-fifareforms

Rossi, G., Semens, A. and Brocard, J.F. (2016) Sports agents and labour markets: evidence from world football. Routledge.

Shrestha, B. and Giron, G. (2006) Regional Capacity Building Workshop on Monitoring and Evaluation Tools and Mechanisms, Save the Children. Available at: https://resourcecentre.savethechildren.net/sites/default/files/documents/1761.pdf

Van der Meij, N., Darby, P. and Liston, K. (2017) The downfall of a man is not the end of his life": Navigating involuntary immobility in Ghanaian football'. Sociology of Sport Journal. 34(2) 183-194. 
Yilmaz, S. (2018) Protection of minors: lessons about the FIFA RSTP from the recent Spanish cases at the Court of Arbitration for Sport. The International Sports Law Journal doi.org/10.1007/s40318-018-0126-y

World Players Association, (2017) Universal Declaration of Players Rights. Available at: $\quad$ http://www.uniglobalunion.org/sites/default/files/imce/world players udpr 1-

page 0.pdf 